\title{
Figures acknowledgements
}

o.I (p. xiv) Map of the medieval world, c. 6oo-I400.

Outline map created from digital map data (C) Collins Bartholomew Ltd [5/or/o6]. Reproduced by Kind Permission of HarperCollins Publishers

I.I (p. I I) Aristotle giving instruction to Alexander the Great. London, British Library, APAC, MS Or. 2784, fol. 96a (undated, Baghdad, I 3 th cent.?). Reproduced with permission of The British Library

I.2 (p. I4) Branch diagrams from the Summary (Jawāmi') of the Treatise by Galen on Simple Drugs, with explanatory translation alongside.

Oxford, Bodleian Library, Oriental Collections, MS Hunt. 6oo, fol. I $5 \mathrm{~b}$ (undated, I2-I $3^{\text {th }}$ cent.?). Reproduced with permission of The Bodleian Library

I.3 (p. 34) The Abridgment (Talkhīs) by Ibn Maymūn (Maimonides, d. I 204) of Galen's Method of Healing.

Paris, BnF, MS heb. I203, folio 45b (i2th cent.). Reproduced by permission of the Bibliothèque nationale de France

2.I (p. 42) Arabic translation of Galen's On [Medical] Sects for Beginners, with important owners' signatures.

Paris, BnF, MS arabe 2859 , fol. ia (early i ith cent.). Reproduced by permission of the Bibliothèque nationale de France

2.2 (p. 43) The four elements, humours, primary qualities, and temperaments as they relate to the seasons, the ages of man, the months, and the zodiacal constellations.

(C) E. Savage-Smith

2.3 (p. 46) The movement of blood according to the Galenic model and according to Ibn al-Nafīs.

(c) E. Savage-Smith

2.4 (p. 52) The illustration of 'horsetail', a variety of Equisetum sylvaticum L., from a copy of the Greek treatise by Dioscorides on medicinal substances. Vienna, Österreichische Nationalbibliothek, Cod. med. grec. I, folio I 44V (copied c. 5ro). Reproduced with permission of the Austrian National Library, picture archives 
2.5 (p. 66) The muscles of the eye, from Hunayn ibn Ishāq's Ten Treatises on the Eye.

Cairo, Dār al-Kutub, MS Ṭibb Taymūr 100 (copied in Syria, 1197), page 316. Reproduced with permission from Dār al-Kutub al-Miṣrīyah, Cairo

2.6 (p. 69) A Karshuni copy of The Almanac of Bodily Parts for the Treatment of People by Ibn Jazlah.

Glasgow, University Library, Spec. Coll., MS Hunter 40, fols. 15b-16a (undated, c. 15th cent.). Reproduced with permission of The University Library, Glasgow

3.1 (p. 97) Cupping, as depicted in a thirteenth-century copy of the Assemblies (Maqāmāt) by al-Harīīi.

St Petersburg, Institute of Oriental Studies, MS C23, fol. 165a. Reproduced courtesy of the St Petersburg Branch of the Institute of Oriental Studies, Russian Academy of Sciences

3.2 (p. 99) The Manșūrī hospital complex, from Pascal Xavier Coste, Architecture arabe ou monuments du Kaire (Paris: Firmin-Didot, 1839), Plate XV. The labels have been added on the basis of identifications given by Coste. Reproduced with permission of the Bodleian Library, shelfmark Mason Y 60

3.3 (p. 106) The hour of birth in a copy of the Assemblies (Maqāmāt) by alHarīīi.

Paris, BnF, MS arabe 5847, fol. 122b (painted in 1237, probably in Baghdad). Reproduced by permission of the Bibliothèque nationale de France

4.1 (p. I23) A physician with two patients, illustrating the Arabic translation of Dioscorides' treatise on medicinal substances.

Washington, D.C., Arthur M. Sackler Gallery, Smithsonian Institution; Purchase-Smithsonian Unrestricted Trust Funds, Smithsonian Collections Acquisition Program, and Dr Arthur M. Sackler, SI986.97a (copied in Baghdad, 1224). Reproduced with permission from the Sackler Gallery, Smithsonian Institution

4.2 (p. I26) The instruments illustrated in The Sufficient Book on Ophthalmology, by Khalīfah ibn Abī al-Mahāsin al-Halabī.

Paris, BnF, MS arabe 1043, fols. 42b-43a (copied in Syria, c. 1256-75). Reproduced by permission of the Bibliothèque nationale de France

4.3 (p. 137) A scene in a steam bath (hammām), illustrating a copy of the Khamsah ('Quintette') by Nizāmī.

Dublin, Chester Beatty Library, Persian MS 195, fol. 33a (painted in 1529). (C) The Trustees of the Chester Beatty Library, Dublin

5.1 (p. 147) The budūh magic square.

(c) E. Savage-Smith 
5.2 (p. I49) A design for a gemstone from The Book of the Oblique by alBūnī.

London, The Nasser D. Khalili Collection of Islamic Art, MS 300, fol. 71a (copied in 1425). Reproduced by permission of the Nasser D. Khalili Collection of Islamic Art

5.3 (p. 152) A magic-medicinal bowl made in 1169-70 for Nūr al-Dīn Maḥmūd ibn Zangī.

London, The Nasser D. Khalili Collection of Islamic Art, MTW 1443. Reproduced by permission of the Nasser D. Khalili Collection of Islamic Art

6.1 (p. r63) A 'portrait' of al-Rāzī in a copy made in 1443 of the ninth book of the Latin translation of The Book for al-Manșūr by al-Rāzī.

Oxford, Bodleian Library, Dept. of Western Manuscripts, MS Canon. Misc. 566, fol. 1r (copied in 1443). Reproduced with permission of The Bodleian Library

6.2 (p. I 74) A traditional Unani doctor (hakim) surrounded by pouches of medicines, with a servant seated alongside.

London, British Library, APAC, MS Add. Or. 1585, fol. 2r (drawn in c. 1856). Reproduced with permission of The British Library

6.3 (p. г 76) A vendor of traditional remedies in the city of Ta ${ }^{\prime} i z$ in Southern Yemen.

Photo taken in July 1993 by Prof. L. P. H. M. Buskens. C L. P. H. M. Buskens, reproduced here with his kind permission

The publisher is grateful to the various libraries, institutions, and individuals for permission to reproduce the illustrations. 


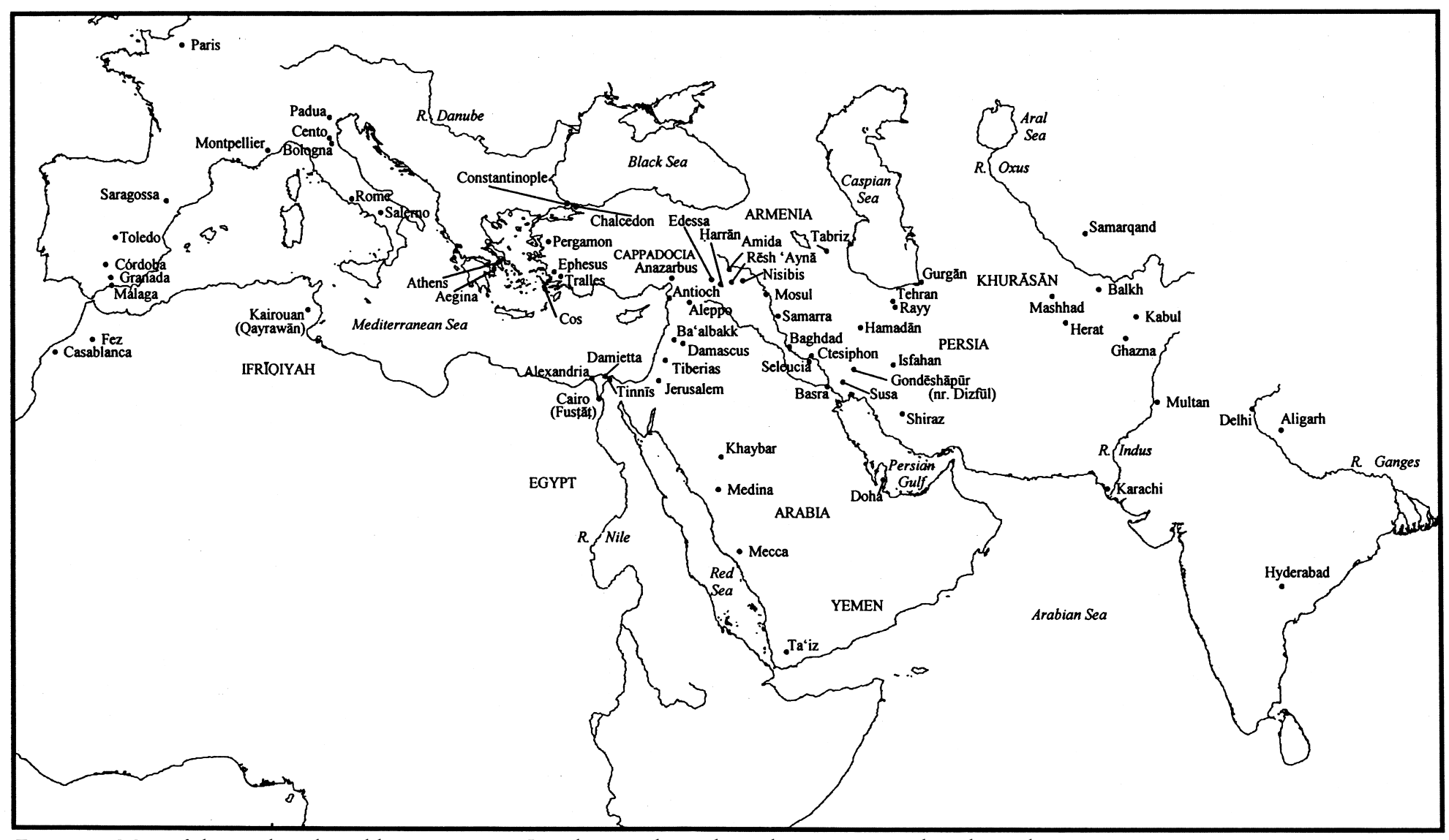

Figure 0.I Map of the medieval world, c. 600-I 400. Localities indicated are those mentioned in this volume. 